\title{
PENGARUH MODEL PEMBELAJARAN INKUIRI TERHADAP HASIL BELAJAR SISWA PADA MATERI POKOK PENGUKURAN DI KELAS X SEMESTER I SMA NEGERI 1 AEK NATAS T.P 2014-2015
}

\author{
Fitriana dan Juru Bahasa Sinuraya \\ Program Studi Pendidikan Fisika FMIPA Uimed \\ Hsb_fitriana@yahoo.com
}

\begin{abstract}
Abstrak
Penelitian ini menerapkan model pembelajaran inkuiri, yang bertujuan untuk mengetahui hasil belajar siswa dan aktivitas belajar siswa. Penerapan model pembelajaran inkuiri ini didasarkan atas kelebihannya yang menekankan pada penemuan siswa sendiri dari sesuatu yang dipertanyakan dan diarahkan pada aktivitas siswa melalui eksperimen. Dalam proses pembelajaran inkuiri ini dapat mengembangkan keterampilan berpikir siswa dan melibatkan sejumlah pengalaman siswa.Penelitian dengan metode kuasi eksperimen ini melibatkan serangkaian kegiatan yang meliputi mendapat perhatian dan menjelaskan proses inkuiri, menyajikan permasalahan, siswa merumuskan hipotesis, mengumpulkan data melaui eksperimen, analisis data dan kesimpulan, merupakan serangkaian kegiatan mencari dan menemukan serta merumuskan sendiri penemuannya melalui eksperimen lebih bertahan lama dan lebih bermakna daripada sekedar membaca, mengingat dan memahami seperti yang diterapkan di kelas kontrol. Dapat dilihat dari hasil penelitian bahwa hasil belajar siswa mengalami perbedaan antara kelas eksperimen dan kelas kontrol. Skor rata-rata pretes siswa di kelas eksperimen adalah 37,77 dan di kelas kontrol 38. Setelah diberi model pembelajaran inkuiri di kelas eksperimen dan pembelajaran konvensional yang berupa metode ceramah dan tanya jawab di kelas kontrol, menunjukkan adanya perbedaan hasil belajar siswa pada postes di kedua kelas. Skor rata-rata postes di kelas eksperimen 70,43 dengan standar deviasi 13,18, sedangkan di kelas kontrol 60,43 dengan standar deviasi 14,04. Perbedaan skor rata-rata ini menunjukkan adanya pengaruh model pembelajaran inkuiri terhadap hasil belajar siswa.

Selain berpengaruh terhadap hasil belajar siswa, model pembelajaran inkuiri juga meningkatkan aktivitas belajar siswa yang dapat diamati dengan peningkatan aktivitas dari pertemuan pertama sampai pertemuan ketiga dengan kategori; $60 \%$ mendapat kategori cukup aktif, 40\% mendapat kategori sangat aktif dan kategori sangat tidak aktif dan kurang aktif $0 \%$. Dengan demikian dapat disimpulkan bahwa ada pengaruh yang signifikan dari model pembelajaran inkuiri terhadap hasil belajar siswa pada materi pokok pengukuran kelas X SMA N 1 Aek Natas T.P. 2014-2015
\end{abstract}

Kata Kunci :Inkuiri, Hasil belajar, Aktivitas, Pengukuran 


\begin{abstract}
This research applies inquiry learning model, which aims to determine student learning outcomes and student learning activities. Application of inquiry learning model is based on the excess which emphasizes the student's discovery of something that is questionable and directed the activities of the students through the experiment. In the process of this inquiry learning can develop the thinking skills of students and involve a number of student experience. Quasi-experimental research method involves a series of activities that include attention and explain the proceedings, presenting problems, students formulate hypotheses, collect data through experiments, data analysis and conclusions, is a series of activities, seek and find and formulate their own discoveries through experimentation more lasting and more meaningful than just read, remember and understand as it is applied in the control class. It can be seen from the results that the learning outcomes of students experience the difference between the experimental class and the control class. Average scores of students in the experimental class pretest was 37.77 and in the control class 38. Having given inquiry learning model in the experimental class and conventional learning in the form of a lecture and question and answer in class control, showed differences in student learning outcomes at post-test in second grade. The mean score on the posttest experimental class 70.43 with a standard deviation of 13.18 , while in the control class 60.43 with a standard deviation of 14.04. The difference in mea.n score indicates the influence of inquiry

learning model for student learning outcomes. Besides effect on student learning, inquiry learning model also increases student learning activities that can be observed with an increase in activity from the first meeting to the third meeting of the category; $60 \%$ got a pretty active category, $40 \%$ got a very active category and the category is not very active and less active 0\%.It can be concluded that there is a significant effect of inquiry learning model for student learning outcomes measurement in the subject matter of class X SMA N 1 AEK Natas TP 2014-2015
\end{abstract}

Keywords: Inquiry, learning outcomes, activities, Measurement 


\section{PENDAHULUAN}

Pendidikan adalah salah satu bentuk perwujudan kebudayaan manusia yang dinamis dan syarat perkembangan. Oleh karena itu, perubahan atau perkembangan pendidikan adalah hal yang memang seharusnya terjadi sejalan dengan perubahan atau perkembangan budaya kehidupan. Berbagai upaya telah dilakukan oleh pemerintah dalam meningkatkan mutu pendidikan di Indonesia, namun sampai saat ini belum memperoleh hasil yang optimal. Khususnya pada pelajaran fisika yang dianggap siswa sulit sehingga mempengaruhi minat siswa. Berdasarkan hasil wawancara kepada salah satu guru fisika di SMA N 1 Aek Natas yaitu ibu Nurcahaya mengatakan bahwa hanya $30 \%$ siswa yang lulus fisika dari setiap ulangan harian fisika yang dilakukan. Demikian pula nilai fisika pada semester sebelumnya hanya $30 \%$ siswa yang lulus Kriteria Kelulusan Minimal (KKM). Selain itu, dilihat dari kategori soal yang diberikan hanya berkisar pengetahuan (C1), pemahaman (C2) dan penerepan atau menghitung (C3), bahkan soal yang diberikan lebih banyak menghitung yang menggunakan rumus atau C3, sehingga membuat siswa merasa sulit dalam mengerjakan soal. Itulah sebabnya siswa banyak beranggapan bahwa pelajaran fisika adalah pelajaran yang paling sulit dari pelajaran yang lain.

Hasil belajar diatas menunjukan bahwa berbagai pendekatan, gagasan atau inovasi dalam dunia pendidikan fisika yang sampai saat ini diterapkan secara luas ternyata belum memberikan perubahan yang positif yang berarti, baik dalam proses pembelajaran fisika di sekolah maupun dalam meningkatkan mutu pendidikan fisika pada umumnya. Kesadaran tentang pentingnya pendidikan yang dapat memberikan harapan dan memungkinkan yang lebih baik di masa mendatang, telah mendorong berbagai upaya dan perhatian seluruh masyarakat terhadap setiap langkah dan perkembanagn dunia pendidikan. Untuk meningkatkan pendidikan di indonesia pemerintah membuat perubahanperubahan baru diantaranya kurikulum 2013 yang merupakan kurikulum berbasis karakter, kurikulum ini menakankan pengembangan karakter dan aktivitas siswa siswa.

Fisika adalah salah satu cabang lmu Pengetahuan Alam (IPA) yang merupakan suatu ilmu pengetahuan yang mempelajari gejala-gejala alam dan interaksi didalamnya. Pelajaran fisika pada umumnya lebih menekankan pada ranah kognitif untuk meningkatkan kompetensi sehinggan kurang mampu berpikir kritis dan sistematis dalam pemahaman konsep fisika, pemahaman terhadap konsep pelajaran fisika akan sangat berpengaruh terhadap hasil belajar siswa.

Pelajaran fisika sampai saat ini masih dianggap pelajaran yang paling sulit dan mata pelajaran yang paling tidak disukai oleh siswa, hal ini disebabkan karena metode mengajar disajikan kurang bervariasi sehingga kurang menarik minat siswa untuk belajar fisika.

Berdasarkan wawancara peneliti di SMA N 1 Aek Natas diperoleh informasi bahwa model pembelajaran yang dilakukan guru adalah model pembelajaran konvensional, yakni metode yang digunakan adalah ceramah, mencatat dan mengerjakan soal dan pembelajaran hanya berlangsung satu arah, sehingga siswa menjadi kurang aktif dalam belajar karena dalam pembelajaran yang berlangsung terjadi teacher centre bukan student centre. Guru tidak mengikut sertakan siswa dalam pembelajaran. Walaupun siswa diberi kesempatan untuk bertanya hanya sedikit siswa yang melakukannya bahkan tidak ada. Hal ini terjadi karena siswa masi takut atau bingung mengenai apa yang ia tanyakan.

Untuk mengatasi masalah diatas perlu pemecahan yaitu dengan melakukan tindakan yang dapat merubah suasana pembelajaran yang melibatkan siswa (student centre). Untuk itu perlu diterapkan model pembelajaran inkuiri. Alasan menggunakan model pembelajaran ini adalah siswa akan mendapatkaan pemahaman-pemahaman yang lebih baik karena setelah berhipotesis siswa memecahkan masalah sendiri melalui eksperimen yang dilakukannya. Model pembelajaran inkuiri merupakan bagian dari pembelajaran fisika yang sangat penting karena dalam proses pembelajaran siswa dimungkinkan memperoleh pengalaman 
menggunakan pengetahuan serta keterampilan yang sudah dimiliki untuk diterapkan dalam pemecahan masalah yang bersifat tidak rutin. Model pembelaran inkuiri memberikan kesempatan kepada siswa untuk berperan aktif dalam mempelajari, mencari, dan menunjukan sendiri informasi atau data untuk diolah menjadi konsep ,prinsip, atau kesimpulan.

Hasil penelitian yang dilakukan oleh Lubis (2011) dengan penelitian Pengaruh model pembelajaran Inquiry terhadap hasil belajar siswa pada materi pokok suhu dan pengukuran di kelas VII diperoleh hasil belajar siswa dengan menggunakan model inkuiri memiliki rata-rata 70,25 dan hasil belajar siswa dengan menggunakan model pembelajaran konvensional memiliki nilai rata-rata 63,63. Peneliti selanjutnya Marita (2012) yang meniliti pengaruh model pembelajaran inkuiri training terhadap hasil belajar siswa pada materi pokok zat dan wujudnya di kelas VII diperoleh nilai rata-rata postes dengan menggunakan model pembelajaran inkuiri 73,1, dan hasil belajar siswa dengan menggunakan model pembelajaran konvensional memiliki nilai rata-rata 66,1.Dari peneliti-peneliti sebelumnya menunjukan bahwa model inkuiri berpengaruh terhadap hasil belajar siswa pada pembelajaran fisika.

Berdasarkan masalah-masalah diatas peneliti tertarik untuk melakukan penelitian dengan judul Pengaruh Model Pembelajaran Inkuiri Terhadap Hasil Belajar siswa pada Materi Pokok Pengukuran kelas X Semester I SMA Negeri 1 Aek Natas Tahun Pembelajaran 2014/2015.

\section{Metode Penelitian}

Penelitian ini dilaksanan di SMA Negeri 1 Aek Natas dengan populasi seluruh siswa kelas X SMA Negeri 1 Aek Natas yang terdiri dari tujuh kelas yang berjumlah 242 siswa. Teknik pengambilan sampel dilakukan dengan cara tehnik sampel keas acak (clauster random sampling). Sampel kelas diambil dari populasi sebanyak dua kelas, yaitu kelas X-1 dengan menggunakan model pembelajaran Inkuiri dan kelas X-4 dengan mengguakan model pembelajaran konvensional.
Hasil belajar siswa diperoleh dengan memberikan tes pada kedua kelas sebelum dan sesudah diberi perlakuan. Rancangan penelitian quasi eksperiment ini dengan Two Group Pretest-Postest Design.

Alat Pengumpulan data dalam penelitian ini adalah tes hasil belajar berbentuk pilihan berganda dengan lima option dan observasi. Tes Hasil Belajar ini digunakan untuk mengetahui kemampuan siswa pada ranah kognitif dan observasi untuk mengetahui aktivitas belajar siswa.

Uji hipotesis digunakan dengan membandingkan rata - rata skor hasil belajar yang dicapai baik kelas eksperimen maupun kelas kontrol. Data yang diperoleh ditabulasikan kemudian dicari rata - ratanya. Sebelum melakukan penganalisisan data, terlebih dahulu ditentukan skor masing masing kelompok sampel lalu dilakukan pengolahan data.

Ujit dua pihak digunakan untuk mengetahui kesamaan kemampuan awal siswa pada kedua kelompok sampel.

Uji t satu pihak digunakan untuk mengetahui pengaruh dari suatu perlakuan yaitu model pembelajaran Inkuiri terhadap hasil belajar siswa.

\section{HASIL DAN PEMBAHASAN}

Observasi dilakukan selama kegiatan belajar mengajar yang dilakukan selama tiga kali pertemuan baik di kelas eksperimen maupun di kelas kontrol. Rata-rata hasil observasi dari pertemuan I sampai pertemuan III untuk kelompok eksperimen dan kelompok kontrol.

Rata - rata aktivitas siswa pada kelas eksperimen pada pertemuan I 493, pertemuan kedua 519, dan pertemuan ketiga 540. Dapat dilihat terjadi peningkatan aktivitas siswa dengan menggunakan model pembelajaran inkuiri dari pertemuan pertama hingga ketiga dengan rata-rata nilai seluruhnya adalah 517 (kategori cukup aktif). Persentase untuk setiap kategori adalah sebagai berikut: 0\% (tidak ada) untuk kategori sangat tidak aktif, 60\% (18 orang ) mendapat kategori cukup aktif, $40 \%$ (12 orang) mendapat kategori sangat aktif dan $0 \%$ (tidak ada) mendapat kategori kurang aktif. 
Peningkatan tersebut diamati dengan 6 indikator yaitu, menjawab pertanyaan, bertanya kepada guru, merumuskan hipotesis, melakukan eksperimen, mengumpulkan dan menganalisis data, dan membuat kesimpulan. Nilai rata - rata dari masing - masing indikator yang diamati adalah sebagai berikut:

Tabel 1 Skor Rata - Rata Aktivitas Yang Diamati

\begin{tabular}{|c|l|l|l|l|l|l|}
\hline & \multicolumn{6}{|c|}{ Skor rata - rata aktivitas yang diamati } \\
\cline { 2 - 7 } & $\begin{array}{l}\text { Me } \\
\text { nja } \\
\text { Perte } \\
\text { muan } \\
\text { Pert } \\
\text { Pert } \\
\text { any } \\
\text { aan }\end{array}$ & $\begin{array}{l}\text { anya } \\
\text { kepa } \\
\text { da } \\
\text { guru }\end{array}$ & $\begin{array}{l}\text { Merum } \\
\text { uskan } \\
\text { Hipotes } \\
\text { is }\end{array}$ & $\begin{array}{l}\text { Melak } \\
\text { ukan } \\
\text { Ekspe } \\
\text { rimen }\end{array}$ & $\begin{array}{l}\text { Meng } \\
\text { umpul } \\
\text { kan } \\
\text { dan } \\
\text { meng } \\
\text { analisi } \\
\text { s data }\end{array}$ & $\begin{array}{l}\text { Memb } \\
\text { uat } \\
\text { Kesim } \\
\text { pulan }\end{array}$ \\
\hline I & 81 & 69 & 80 & 93 & 88 & 84 \\
\hline II & 87 & 74 & 80 & 95 & 91 & 93 \\
\hline III & 90 & 79 & 78 & 97 & 93 & 95 \\
\hline Rata & 86 & 74 & 79,3 & 92,3 & 90,67 & 90,67 \\
rata & & & & & & \\
\hline
\end{tabular}

Dari tabel 1 terlihat bahwa terjadi peningkatan nilai rata - rata aktivitas yang diamati dari pertemuan pertama hingga pertemuan ketiga. Keenam indikator aktivitas belajar siswa yang paling menonjol adalah aspek melakukan eksperimen yakni 17,99\% (dengan rata - rata skor 92,3), selanjuntnya mengumpulkan dan menganalisis data dengan membuat kesimpulan memiliki persentase sama yakni 17,67 \% (dengan skor rata - rata 90,67), selanjutnya aspek menjawab pertanyaan yakni $16,76 \%$ (dengan skor rata rata 86), aspek merumuskan hipotesis dengan persentase $15,45 \%$ (dengan skor rata - rata 79,3), aspek yang terakhir yakni bertanya kepada guru dengan persentase 14,4\% (dengan skor rata - rata 74).

Berdasarkan data hasil penelitian dan hasil analisis diperoleh kesimpulan bahwa model pembelajaran inkuiri dapat meningkatkan aktivitas belajar siswa. Hal ini menunjukkan bahwa model pembelajaran inkuiri tidak hanya meningkatkan hasil belajar saja, tetapi juga mampu meningkatkan aktivitas siswa. Ternyata aktivitas ini juga memiliki kontribusi yang cukup besar terhadap hasil belajar yaitu dilihat dari nilai rata-rata postes yang cukup baik sebesar 70,43

Berdasarkan data hasil penelitian dan hasil analisis diperoleh kesimpulan bahwa model pembelajaran inkuiri dapat meningkatkan aktivitas belajar siswa. Hal ini menunjukkan bahwa model pembelajaran inkuiri tidak hanya meningkatkan hasil belajar saja, tetapi juga mampu meningkatkan aktivitas siswa. Ternyata aktivitas ini juga memiliki kontribusi yang cukup besar terhadap hasil belajar yaitu dilihat dari nilai rata-rata postes yang cukup baik sebesar 70,43 .

Sebelum pembelajaran, dilakukan tes awal, diperoleh nilai rata - rata tes awal kelas eksperimen sebesar 37,77 dan nilai rata - rata tes awal kelas kontrol sebesar 38. Setelah diberikan perlakuan yang berbeda, dimana pada kelas eksperimen diberikan pembelajaran dengan model pembelajaran inkuiri dan pada kelas kontrol diberikan pembelajaran konvensional, diperoleh rata rata tes akhir kelas eksperimen sebesar 70,43 dan rata - rata tes ahir kelas kontrol sebesar 60,43 . Hal ini berarti hasil belajar siswa pada kelas kontrol mengalami peningkatan sebesar 22,43 dan pada kelas eksperimen sebesar 32,66. Dari hasil ini tampak bahwa nilai tes akhir kelas eksperimen lebih tinggi dibandingkan dengan kelas kontrol denganperbedaan peningkatan sebesar 10,23, sehingga dapat dikatakan bahwa penerapan model pembelajaran inkuiri memberikan peningkatan hasil belajar siswa pada materi pokok pengukuran di kelas X semester I SMA Negeri 1 Aek Natas. Data tes awal dan tes akhir kelompok eksperimen dan kelompok kontrol ditunjukan pada tabel 2.

Tabel 2 Nilai Rata-rata Kelas Eksperimen dan Kelas Kontrol

\begin{tabular}{|l|c|c|}
\hline No & Data & $\begin{array}{c}\text { Nilai Rata- } \\
\text { rata }\end{array}$ \\
\hline 1 & Pretes kelas eksperimen & 37,78 \\
2 & Pretes Kelas Kontrol & 38 \\
3 & Postes Kelas Eksperimen & 70,43 \\
4 & Postes Kelas Kontrol & 60,43 \\
\hline
\end{tabular}

Berdasarkan uji normalitas dengan menggunakan uji Lillifors untuk kedua sampel diperoleh bahwa nilai tes awal dan tes akhir berdistribusi normal seperti ditunjukan pada tabel 3. 
Tabel 3 Hasil Uji Normalitas Data Pretes dan

Tes Postes Kedua Kelompok

\begin{tabular}{|c|c|c|c|}
\hline \multirow{2}{*}{ Kelas } & \multicolumn{2}{|c|}{ Data Pretes } & \multirow{2}{*}{ Kesimpulan } \\
\cline { 2 - 3 } & L hitung & $\mathrm{L}_{\text {tabel }}$ & \\
\hline Eksperimen & 0,1517 & 0,1610 & Normal \\
\hline Kontrol & 0,1295 & 0,1610 & Normal \\
\hline \multirow{2}{*}{ Kelas } & \multicolumn{2}{|c|}{ Data Postes } & \multirow{2}{*}{ Kesimpulan } \\
\cline { 2 - 3 } & L $_{\text {hitung }}$ & $\mathrm{L}_{\text {tabel }}$ & \\
\hline Eksperimen & 0,1032 & 0,1610 & Normal \\
\hline Kontrol & 0,0950 & 0,1610 & Normal \\
\hline
\end{tabular}

Pengujian Homogenitas data pretes dan postes dilakukan dengan uji F. Hasil uji homogenitas data yang diperoleh ditunjukan pada tabel 4, Pretes dan Postes merupakan data yang homogen.

Tabel 4 Hasil Uji Homogenitas Data Pretes dan Postes Kelompok Eksperimen dan Kelompok Kelas Kontrol

\begin{tabular}{|c|c|c|c|c|c|}
\hline No & Data & $\begin{array}{l}\text { Varian } \\
\mathrm{s}\end{array}$ & $\mathrm{F}_{\text {hitung }}$ & $\mathrm{F}_{\text {tabel }}$ & $\begin{array}{l}\text { Kesim } \\
\text { pulan }\end{array}$ \\
\hline 1 & $\begin{array}{l}\text { Pretes Kelas } \\
\text { Eksperimen }\end{array}$ & 127,56 & \multirow{2}{*}{1,27} & \multirow{2}{*}{1,86} & \multirow{2}{*}{$\begin{array}{c}\text { Homo } \\
\text { gen }\end{array}$} \\
\hline 2 & $\begin{array}{ll}\begin{array}{l}\text { Pretes } \\
\text { kontrol }\end{array} & \text { Kelas } \\
\end{array}$ & 161,79 & & & \\
\hline 3 & $\begin{array}{l}\text { Postes Kelasn } \\
\text { Eksperimen }\end{array}$ & 193,74 & \multirow{2}{*}{1,02} & \multirow{2}{*}{1,86} & \multirow{2}{*}{$\begin{array}{l}\text { Homo } \\
\text { gen }\end{array}$} \\
\hline 4 & $\begin{array}{ll}\text { Postes } & \text { Kelas } \\
\text { kontrol } & \end{array}$ & 197,35 & & & \\
\hline
\end{tabular}

Hasil Uji Hipotesis untuk postes menggunakan uji t satu pihak pada taraf signifikan $\alpha=0,05$. Diperoleh bahwa nilai $t_{\text {hitung }}=2,760$ dan nilai ini lebih besar dari nilai $\mathrm{t}_{\text {tabel }}=1,671$, maka $\mathrm{H}_{0}=$ di tolak dan $\mathrm{H}_{\mathrm{a}}$ = diterima. Dengan kata lain hasil belajar siswa menggunakan model pembelajaran inkuiri lebih tinggi daripada hasil belajar siswa dengan menggunakan model pembelajaran konvensional pada materi pokok pengukuran di kelas X semester I SMA Negeri 1 Aek Natas.

Hasil penelitian menunjukkan bahwa pengaruh model pembelajaran inkuiri memberikan hasil belajar siswa lebih tinggi dibandingkan dengan model pembelajaran konvensional pada materi pokok Pengukuran di kelas X semester I SMA N 1 Aek Natas T.P 2014/2015. Hal ini diperkuat dengan perolehan nilai rata-rata pretes siswa di kelas kontrol sebesar 38 dan nilai rata-rata postes sebesar 60,43 sedangkan di kelas eksperimen diperoleh nilai rata-rata pretes siswa sebesar 37,78 dan nilai rata-rata postes sebesar 70,43. Peningkatan hasil belajar siswa kelas kontrol sebesar 22,43 dan kelas eksperimen sebesar 32,65 . Dengan hasil pengujian hipotesis nilai $\mathrm{t}_{\text {hitung }}=2,76$, diperoleh lebih besar dari $\mathrm{t}_{\text {tabel }}=$ 1,67 Ini sejalan dengan hasil penelitian yang dilakukan oleh Yusman (2010) dengan hasil pengujian hipotesis pada penelitian tersebut diperoleh nilai thitung $=2,52$ dengan taraf signifikan 0,05 dengan $t_{\text {tabel }} 1,99$ hal ini menunjukan bahwa hasil belajar siswa dengan menggunakan model pembelajaran inkuiri lebih tinggi dibandingkan dengan menggunakan model pembelajaran konvensional. Hal ini sejalan dengan hasil penelitian yang dilakukan oleh Harahap (2014) dengan hasil pengujian hipotesis diperoleh $t_{\text {hitung }}=3,60$ dan $t_{\text {tabel }} 1,67$ yang menunjukan hasil belajar siswa dengan model pembelajaran inkuiri lebih tinggi daripada hasil belajar siswa dengan model pembelajaran konvensional. Perbedaan hasil belajar tersebut karena didasarkan atas penerapan model pembelajaran inkuiri di kelas eksperimen.

Peningkatan hasil belajar menggunakan model pembelajaran inkuiri lebih baik dikarenakan model pembelajaran ini memiliki beberapa kelebihan yaitu : 1) siswa belajar untuk menemukan jawaban sendiri melalui eksperimen yang dilakuakannya sehingga siswa seperti ilmuan; 2) merangsang keingintahuan dan memotivasi kemampuan siswa; 3) siswa didorong untuk belajar sendiri, belajar aktif melalui konsepkonsep, prinsip-prinsip; 4) mengajarkan siswa untuk memahami isi dan proses dalam waktu yang bersamaan; 5) siswa memperoleh rasa kepuasan sendiri, hal ini dapat dilihat pada saat siswa bekerja bersama kelompok mengemukakan hipotesis mereka dan pada saat siswa bertanya kepada peneliti serta pada saat siswa mengemukakan pendapat atau mengemukakan apa yang telah mereka dapat dalam proses pembelajaran tersebut; 6) siswa juga dituntut belajar sambil berbuat sehingga siswa lebih mengingat apa yang telah mereka pelajari. Hal yang sama juga disebutkan oleh Wirthab dan Rapi (2008) dengan judul penelitian Pengaruh Model Pembelajaran dan Penalaran Formal terhadap Penguasaan 
Konsep Fisika dan Sikap Ilmiah Siswa SMA N 4 Singaraja. Model pembelajaran inkuiri memberikan kesempatan kepada siswa untuk bekerja seperti ilmuan merumuskan hipotesis, menngali informasi, dan memlakukan atau merancang percobaan dan mengkomunikasi hasil percobaan, jadi guru dalam pembelajaran ini adalah sebagai fasilitator.

Apabila langkah-langkah model pembelajaran inkuiri dapat dilakukan seefektif mungkin dan kendala-kendala dapat diatasi maka model pembelajaran inkuiri dapat dijadikan salah satu model pembelajaran yang dapat memperbaiki hasil belajar fisika siswa. Disamping itu model pembelajaran inkuiri juga menekankan kepada aktivitas belajar siswa yakni proses keterlibatan siswa secara aktif dalam menemukan sendiri materi yang dipelajari dan menghubungkannya dengan lingkungan sehingga mendorong siswa untuk dapat menerapkannya dalam kehidupan sehari-hari. Inkuiri tidak hanya membuat siswa berperan sebagai penerima materi secara verbal, tetapi juga berperan menemukan dan merumuskan sendiri inti dari materi yang diajarkan.

Dari hasil pengamatan yang dilakukan oleh teman peneliti sebagai observer, diperoleh bahwa aktivitas siswa mengalami peningkatan yang positif yaitu pada pertemuan I diperoleh aktivitas dengan kategori aktif sebanyak 18 orang dan cukup aktif 9 orang dan kurang aktif 3 orang. Hal ini terjadi karena ada beberapa orang yang belum terbiasa dengan model pembelajaran ini. Diperoleh lebih dari $50 \%$ aktivitas siswa memiliki kategori aktif. Pada pertemuan II diperoleh aktivitas dengan ketegori aktif tetap 18 orang, tetapi pada pertemuan ini tidak ada lagi siswa yang termasuk kategori kurang aktif melainkan cukup aktif sebanyak 12 orang. Hal ini terjadi karena pembelajaran membuat siswa mulai termotivasi bekerjasama dengan kelompok, mengajukan dan menjawab beberapa pertanyaan. Pada pertemuan III diperoleh aktivitas dengan kategori aktif sebanyak 21 siswa, selebihnya pada kategori cukup aktif 9 orang. Hal ini terjadi karena pembelajaran membuat siswa semakin aktif dan kreatif dalam memecahkan masalah melalui kerjasama dengan kelompok, mengajukan pertanyaan dan menjawab pertayaan yang diajukan. Ternyata, aktivitas siswa yang dikategorikan baik sejalan dengan peningkatan hasil belajar siswa yang juga dikategorikan aktif yaitu 66,88. Dalam hal ini, aktivitas siswa memiliki pengaruh positif terhadap hasil belajar.

Namun disamping kelebihan tersebut, model pembelajaran inkuiri juga memiliki kelemahan yang menyebabkan hasil pencapaian hasil belajar belum maksimal dan peningkatan hasil belajar masih tergolong rendah, kelemahan tersebut antara lain : 1) seharusnya pada pertemuan pertama peneliti memberikan animasi atau percobaan terlibih dahulu kepada siswa, agar sebelum pembelajaran siswa tau tahap - tahap pembelajaran inkuiri. 2) terlihat pada saat siswa dituntut berfikir kritis dan logis yaitu pada saat pengumpul data yang relevan, ada beberapa siswa yang lebih memilih duduk diam dan menunggu hasil yang diperoleh oleh temannya daripada bergabung membantu temannya untuk memperoleh data tersebut; 2) keterbatasan peneliti dalam mengalokasikan waktu pada saat siswa mengajukan hasil diskusi mereka sehingga tidak semua kelompok dapat menyajikan hasil diskusi mereka; 3) kurangnya pengalaman peneliti dalam mengelola kelas sehingga kondisi siswa yang ribut menyebabkan penelitian menjadi kurang efisien. 4) karekter siswa yang cenderung terbiasa dengan model pembelajaran sederhana dan sebagainya. Model inkuiri menuntut siswa untuk melibatkan dirinya oleh karena itu sebelum melakukan model pembelajaran inkuiri siswa dibiasakan dulu selama beberapa waktu selama dilakukan penelitian sehingga mereka terbiasa.

\section{Kesimpulan}

Setelah melakukan penelitian, perhitungan dan analisis data, maka diperoleh beberapa kesimpulan antara lain sebagai berikut (1) Hasil belajar siswa yang diberikan perlakuan dengan menggunakan model pembelajaran inkuiri pada materi pokok Pengukuran di kelas $\mathrm{X}$ semester I SMA N 1Aek Natas T.P 2014/2015 adalah 70,43. Nilai tersebut termasuk kategori baik dan mencapai Kreteria Ketuntasan Minimal (KKM). (2) Hasil belajar siswa yang 
diberikan perlakuan dengan menggunakan model pembelajaran konvensional pada materi pokok Pengukuran di kelas X semester I SMA N 1Aek Natas T.P 2014/2015 adalah 60,43 . Nilai tersebut termasuk kateogori cukup dan belum mencapai Kreteria Ketuntasan Minimal (KKM). (3) Aktivitas belajar siswa dengan menerapkan model pembelajaran inkuiri pada materi pokok Pengukuran di kelas X semster I SMA N 1 Aek Natas T.P 2014/2015 adalah 59,33 atau cukup aktif. (4) Ada pengaruh yang signifikan dengan menerapkan model pembelajaran inkuiri terhadap hasil belajar siswa pada materi pokok Pengukuran di kelas X semster I SMA N 1 Aek Natas T.P 2014/2015

\section{Saran}

Berdasarkan kesimpulan di atas, maka penulis memberikan beberapa saran sebagai berikut (1) Pelaksanaan pembelajaran dengan model inkuiri dapat meningkatkan hasil belajar siswa sebab model pembelajaran ini menjadikan siswa menemukan sendiri jawaban melalui eksperimen yang dilakukannya dan merangsang keingintahuannya, oleh karena itu disarankan Bagi peneliti lanjut yang ingin melakukan penelitian dengan menggunakan model pembelajaran inkuiri agar menyiapkan fenomena - fenomana yang menarik yang diajukan kepada siswa untuk melatih siswa berhipotesis dan memotivasi kemampuannya. dan lembar kegiatan siswa disarankan membuat perencanaan yang baik dan banyak mempersiapkan masalah - masalah dalam kehidupan sehari - hari untuk menarik perhatian siswa. (2) Model pembelajaran inkuiri juga memiliki kelemahan yang menyebabkan hasil pencapaian hasil belajar belum maksimal karena keterbatasan peneliti dalam mengalokasikan waktu pada saat mengajukan hasil diskusi tidak semua kelompok dapat menyajikan hasil diskusinya. Oleh karena itu disarankan bagi para peneliti selanjutnya yang ingin meneliti tentang model pembelajaran inkuiri lebih lanjut agar menggunakan waktu seefektif mungkin agar tercapai tujuan yang diinginkan. (3) Model pembelajaran inkuiri adalah model pembelajaran yang menekan kemampuan berpikir dan logis siswa oleh karena itu disarankan pada peneliti selanjutnya yang ingin meneliti mengenai model pembelajaran inkuiri alangkah baiknya jika menerapkan model pembelajaran tersebut pada siswa yang memiliki kemampuan berpikir dan logis. Hal tersebut agar tujuan yang diharapkan sesuai teori pembelajaran inkuiri dapat tercapai dengan efektif.

\section{Datfar Pustaka}

Arends, R., (2013), Belajar untuk Mengajar LearningTo Teach Edisi ke 9, Salemba Human, Jakarta

Arikunto, S., (2006), Dasar-Dasar Evaluasi Pendidikan, Penerbit Bumi Aksara, Jakarta.

Arikunto, S., (2008), Dasar-Dasar Evaluasi Pendidikan, Penerbit Bumi Aksara, Jakarta.

Dahar,WR., (2011), Teori-Teori Belajar dan Pembelajaran, Erlangga, Jakarta

Hamalik, O., (2010), Proses Belajar mengajar, Bumi Aksara, Bandung.

Harahap, A.R., (2014),Pengaruh Model Pembelajaran Inkuiri Terhadap hasil Belajar Siswa Pada Materi Pokok Listrik Dinamis di Kelas X SMA Swasta Al Ulum Medan T.P. 2013/2014, FMIPA Unimed, Medan

Jauhar, M.,(2011), Implementasi PAIKEM dari Behavioristik Sampai

Kontruktivistik, Prestasi Pustaka, Jakarta

Lubis,U.R., (2011), Pengaruh Model Pembelajaran inqury terhadap Hasil Belajar Siswa pada Materi Pokok Suhu dan Pengukukuran Di Kelas VII Semester II SMP Negeri 2 Medan Tahun Pelajaran 2010/2011, Skiripsi Program Studi Pendidikan, FMIPA Unimed, Medan

Marita, D., (2012), Pengaruh Model Pembelajaran inquiry Training 
Terhadap Hasil Belajar Siswa Pada Materi Pokok Zat dan Wujudnya dikelas VII Semester I MTs Negeri 3 Medan Tahun Ajaran 2012/2013,Skripsi Program Studi Pendidika, .FMIPA Unimed, Medan

Sanjaya,W., (2011), Strategi Pembelajaran Berorientasi Standar Proses Pendidikan , Kencana, Jakarta

Sudijono,A., (1994), Pengantar Evaluasi pendidikan, Rajawali Pers, Jakarta

Sudjana., (2002), Metoda Statistika, Tarsito, Bandung

Sudjana, N., (2009), Penilaian Hasil Proses Mengajar, PT. Rosdakarya, Bandung.

Sugiono.,(2010), Metode Penelitian Kuantitatif Kualitatif dan $R$ dan $D$, Alfabeta, Bandung

Sukardi., (2008), Metodologi Penelitian Pendidikan, Bumi Aksara, Yogyakarta

Slameto., (2003), Belajar dan Faktor-fakror yang Mempengaruhinya, Jakarta, Rineka Cipta
Sugiono., (2009), Metode Penelitian Pendidikan,Alfabeta, Bandung

Syah, M., (2010), Psikologi Pendidikan, Rosda, Bandung

Trianto., (2011),Mendesain Model pembelajaran Inovatif-Progresif, kencana, jakarta

Trianto., (2009), Mendesain Model pembelajaran Inovatif-Progresif, Kencana,jakarta

Wirtha,I.M., dan Rapi, N.K., (2008), Pengaruh Model pembelajaran Formal Terhadap Penguasaan Konsep Fisika dan Sikap Ilmiah Siswa SMA N 4 Singaraja, Jurnal Penelitian dan pengembangan penelitian :15-29

Yusman, A., (2010), Pengaruh Model Pembelajaran Inkuiri Terhadap Hasil Belajar Fisika Siswa Pada Materi Pokok Gerak, UIN Syarif Hidayatullah, Jakarta 